\title{
Building Students' Moral Through Uswatun Hasanah Principles: A Systematic Literature Review
}

\author{
Kandiri Kandiri' ${ }^{1}$, Arfandi Arfandi ${ }^{2}$, Moh. Zamili ${ }^{3}$, Masykuri \\ Masykuri ${ }^{4}$ \\ 1,2,3,4Universitas Ibrahimy, Indonesia
}

\section{Article History:}

Submitted:

17-05-2021

Accepted:

13-09-2021

Published:

22-09-2021

\begin{abstract}
:
School or madrasah needs to instill good attitudes in the form of speech and behavior in daily activities. The prophet taught Muslims a good example (uswatun hasanah) for students when they gathered and interacted with different communities. Uswatun hasanah, or excellent conduct, is an Islamic religious value born from training and habitual action by providing a good example. Religious and moral education is essential as the root of forming a believer-pious person. This study seeks to understand uswatun hasanah through systematic literature by exploring knowledge patterns in the national database. The results indicate that good moral guidance (uswah) is not based on theoretical teaching but necessitates concrete examples through the role and responsibility of educators in the context of learning and learning processes. As such, educators should be an example (uswatun hasanah) (a good example) for students through excellent conduct in day-to-day activities.
\end{abstract}

Keywords: morals; learner; uswah; educators 


\section{Introduction}

School or madrasah become an important place for individual students to achieve goals. Educational institutions need to provide moral coaching to facilitate students in developing their morals. To improve students' morality, they are required a role model who can be exemplified or uswah hasanah ${ }^{1}$ through the curriculum contained in a set of subjects (such as Moral Education, Pancasila Education, and citizenship). Students also need religious habituation programs and SenyumSalam-Sapa (Smile, Salam, and Greeting) (3S) by school residents or madrasah. Morals are the standard determining the excellent behavior of individuals containing content of values or norms from the soul. They cover three areas, namely behavior, cognition, and affection (a religious

1 Deni Sutisna, Dyah Indraswati, and Muhammad Sobri, "Keteladanan Guru Sebagai Sarana Penerapan Pendidikan Karakter Siswa," JPDI (Jurnal Pendidikan Dasar Indonesia) 4, no. 2 (October 2019): 29, https://doi.org/10.26737/jpdi.v4i2. 1236. perspective that departs from the teachings of tawhid about the appreciation and practice of Islamic teachings are divided into three aspects, namely faith, Islam, Ihsan). Morals from a religious perspective could also be seen from the Islamic value system. Islamic education aims at improving morality; then the Islamic moral system develops through Islamic education oriented to Islamic values; fourth, moral education starts from the family (informal) while applying the reward method - punishment ${ }^{2}$.

Community expectations of teachers who are educating to set a good example in terms of "speech and behavior" is, in fact in recent years it is signaled that there is a low moral decadence of teacher behavior, namely: 1) Teachers do not meet the hours of teaching duties, 2) teachers abandon students in the learning hours, 3) There are teachers and two administrative staff held a

2 Sahmiar Pulungan, "Membangun Moralitas Melalui Pendidikan Agama," Al-Hikmah: Jurnal Agama Dan Ilmu Pengetahuan 8, no. 1 (April 2011): 9-24. 
farewell recall by way of exploring Bali, 4) There was a teacher beat his students to death, 5) There was a teacher who was busy affairs outside his teacher, such as managing the project and so on, 6) There was a lecturer who could kill his wife.

This social phenomenon requires the attention of various parties, especially education circles, which emphasize character building into something that should be applied. Education is the largest field of investment in building and shaping men ${ }^{3}$. That is, the quality of education determines the quality of a nation. Indonesia has a high level of education. The role of education is very important in improving the quality of education as the main support for achieving educational goals. Muhammad Al-Mighfar in Zakiyah Darajat, "Adolescence is a transitional

${ }^{3}$ Muhammad Mushfi El Iq Bali and Nurul Fadilah, "Internalisasi Karakter Religius Di Sekolah Menengah Pertama Nurul Jadid," Jurnal MUDARRISUNA: Media Kajian Pendidikan Agama Islam 9, no. 1 (July 2019): 1-25, https://doi.org/10.22373/jm.v9i1.41 25. period from childhood to adulthood"4, then in adolescence, strict attention is needed from parents and teachers, in addition to that, moral development can also be done by doing a very discipline, especially at school. This is following the words of Allah SWT. Meaning: Indeed, there has been in (himself) Rasulullah SAW that is a good role model for you (that is) for those who hope (mercy) of Allah SWT and the coming of the Day of Judgment, and He mentions Allah SWT a lot. The above verse is very clear: the Prophet Muhammad SAW as a messenger can be used as an example or role model because he was made the profile of an educator with a good personality.

\section{Method}

This study incorporated a systematic literature review in the national database, namely Moraref, to search the conceptualization of uswatun hasanah dan moral education. This review offers guidance for future research in moral

4 Muhammd Al-Mighwar, Psikologi Remaja, 2nd ed. (Bandung: Pustaka Setia, 2011). 
education and uswatun hasanah, which could lead to the creation of a conceptual framework on moral and religious education. The key search used in this study was uswatun hasanah, uswah, moral education, teaching by example within the Islamic education database. In terms of the analysis, the study looked at the pattern that emerged from the database around uswatun hasanah and education.

\section{Results}

Muslim educators need to follow good examples in the form of their speech, silence, and behavior from the prophet Muhammad SAW in their teaching and learning. The positives and negatives of the teacher's personality will be able to have a significant impact on students; therefore, in teaching and learning activities, the teacher must have a noble character that students can emulate because this will be a new indicator of the success of students in participating in learning activities $^{5}$.

5 Abdul Rachman Shaleh, Pendidikan Agama Dan Pembangunan
Thus, the attitude and personality of the teacher will have a significant impact, because if the students have a negative image of the teacher's personality, it will hamper the learning and will have an impact on the achievement of achievement and learning outcomes of the students are not maximal ${ }^{6}$.

A teacher as an educator and teaching staff is undoubtedly required to have personal competence in teaching and learning activities; by having that competence, a teacher must have a solid, stable, mature, wise, dignified, and disciplined personality?

Religion teaches positive morals because it will become a foothold without any element of coercion from the outside, considering that moral values themselves come from religious beliefs

Watak Bangsa (Jakarta: RajaGrafindo Persada, 2006).

6 Muhibbin Syah, Psikologi Belajar, 2nd ed. (Jakarta: RajaGrafindo Persada, 2013).

7 Judyth Sachs, "Teacher Professionalism: Why Are We Still Talking about It?," Teachers and Teaching: Theory and Practice 22, no. 4 (May 2016): 413-25, https://doi.org/10.1080/13540602.2 015.1082732. 
and awareness ${ }^{8}$. The good moral formation is based not only on spiritual teachings, commands and prohibitions (promises and threats) but also on the teacher's good example (uswah). The analysis focuses on the responsibility of educators and the efforts to build moral learners.

\section{Responsibility of Educator}

Responsibilities of Teachers

Educators are responsible for their duties as a) teacher (delivering a set of subject matter to students under the curriculum guide), b) mentor (showing students on a path that is under applicable life norms), and c) trainer (in delivering material lessons are repeated both theoretically and practically so that students can easily understand them) in formal educational institutions to educate people who are studying knowledge to achieve the expected goals. The responsibility of teachers as public figures and active personnel with the main capacity is educators and teachers in the formal

8 Zakiyah Daradjat, Membina Nilai-Nilai Moral Di Indonesia, 2nd ed. (Jakarta: Bulan Bintang, 2010). education pathways, both TKRA, SD-MI, SMP-Tsanawiyah, SMA-SMK-Aliyah?.

Law of the Republic of Indonesia number 14 of 2005 concerning teachers and lecturers, article 1 paragraph 1 explains that teachers are professional educators with the main task of educating, teaching, directing, training, and evaluating students in early childhood education through formal education, elementary education, and secondary education ${ }^{10}$.

In addition, RI Government Regulation no. 74 of 2008 concerning teacher article 1 describes the seven main tasks of a teacher/educator, namely educating, teaching, guiding, directing, training, assessing, and evaluating students in early childhood education through formal education,

${ }_{9}^{9}$ Depdiknas, “Undang-Undang Nomor 20 Tahun 2003 Tentang Sistem Pendidikan Nasional" (Jakarta, 2003).

10 Depdiknas, “UndangUndang Republik Indonesia Nomor 14 Tahun 2005 Tentang Guru Dan Dosen. Lembaran Negara Republik Indonesia Tahun 2005 Nomor 157," Pub. L. No. 110, 11 (2005). 
primary education, and secondary education ${ }^{11}$.

The teacher of Islamic Education has a responsibility in shaping the morality of students, including:

a. The teachers should motivate students to be active in participating in teaching and learning activities;

b. Teachers should participate in curriculum development in schools;

c. Teachers should provide counseling and guidance for students about; mental, character, personality, physical, and spiritual;

d. Teachers can identify students, both in learning difficulties and looking for alternatives, then evaluate the success and progress of learning outcomes;

e. Teachers conduct classroom research on learning activities;

f. Teachers should take part in society, make lots of friendships, maintain

11 Depdiknas, "Peraturan Pemerintah Republik Indonesia Nomor 74 Tahun 2008 Tentang Guru" (2008). security and order in community;

g. Teachers should practice and live the values contained in Pancasila;

h. Teachers should maintain the stability and conduciveness of the Republic of Indonesia to create peace and unity;

i. Teachers should participate in maintaining the development of both Human Resources and Natural Resources;

j. Teachers should take responsibility for improving the quality and professionalism of teacher status ${ }^{12}$;

k. The role of Teacher.

Carrying out duties as an educator is a very urgent role in learning activities because the teacher's role is as a designer, manager, mentor, educator, trainer, assessor, and evaluating student learning outcomes ${ }^{13}$.

Article 2 paragraph (1) of the Teacher and Lecturer

12 Moh.Uzer Usman, Menjadi Guru Profesional, 3rd ed. (Bandung: Remaja Rosdakarya, 2010).

13 Sutirna, Bimbingan Dan Konseling: Pendidikan Formal, Nonformal, Dan Informal (Yogyakarta: Andi Offset, 2013). 
Law, reads, "Teachers have a position as professional staff at the primary, secondary and early childhood levels of formal education which are appointed under the legislation.", it also explains the function of the teacher's position in article 4, which reads: "The position of professional teachers as referred to in Article 2 paragraph (1) functions to increase the dignity and role of teachers as agents of learning and functions to improve the quality of national education."

The explanation of article 4 in this law states that the role of the teacher as an agent of learning is the role of the teacher as a facilitator, motivator, stimulator, instructor of learning, and inspirer of learning for students ${ }^{14}$.

a. Teacher as facilitator

The teacher should play a role in facilitating students to discover and develop their talents;

b. Teacher as a motivator

14 Depdiknas, Undang-Undang Republik Indonesia Nomor 14 Tahun 2005 Tentang Guru dan Dosen. Lembaran Negara Republik Indonesia Tahun 2005 Nomor 157.
Teachers should play a role in arousing students' enthusiasm for learning;

c. The teacher is the driver Teachers should play a role in lifting and accelerating the achievements of students so that they can be emulated by others 15 ;

d. Teachers as learning engineers

Teachers should be able to engineer learning (creativity) to activate and make every learning effective;

e. The teacher is the inspiration for learning Teachers should inspire learning to improve the quality of student knowledge.

The teacher is a mandate that must be preserved and maintained so that it has positive implications for students, as stated by $E$. Mulyasa, among others:

a. Teacher as educators

Teachers whose capacity is as educators become public figures, role models, and role models for students and the

15 Enco Mulyasa, Menjadi Guru Profesional (Bandung: Remaja Rosdakarya, 2010). 
environment where the teacher is located. Therefore, the teacher must have academic, personal, social, and professional competence and have these competencies; the teacher must also have a measure of personal quality, including teacher independence, teacher discipline, teacher responsibility, and authority. Teachers must understand and know about values, morality, norms, and rules and be committed to behaving and acting by these values and norms.

In addition, a teacher must also be responsible for all his actions in teaching and learning activities and social life. Likewise, the authority of the teacher is; 1 ) teachers must have intellectual, spiritual, and emotional intelligence and have morality, in addition to that 2) teachers must have technological and artistic abilities following the scientific field being developed.

The independence of a teacher must be able to make decisions following what is applicable, which are more priority related to teaching and learning activities and act by the situation and conditions of students, including teachers whose discipline is every teacher's activities according to the rules, norms, and values that apply.

Based on this professional awareness, the teacher is tasked with consistently disciplining students, especially when teaching and learning activities are taking place. Thus, a teacher in maintaining student discipline must start from the teacher himself, because the exemplary and discipline that the teacher has will be a role model for students so that students in teaching and learning activities can achieve the expected competencies.

b. The teacher as a model and role model

A teacher's existence in teaching and learning activities is one figure who will become an example for all students and will also be a role 
model for all elements of society which interact with him. Therefore, whatever is in the teacher will be reflected through his humility, actions, and personality. Teachers who are models and role models are one of the basic characteristics that must be a principle in teaching and learning activities; when a teacher does not pay attention to his role as a role model for his students. This will reduce the seriousness and effectiveness of students in teaching and learning activities because the teacher's personality and role models are certainly a challenge in itself and are the most effective methods in building and shaping students' morale imitating educators' behavior.

According to the exemplary interpretation, it is divided into two, namely; 1) Accidental exemplary is exemplary in science or learning, leadership, and sincerity, 2) deliberate exemplary is exemplary accompanied by explanations or orders to imitate such as the provisions of the procedures for prayer and ablution ${ }^{16}$.

The teacher becomes a role model or educator figure, not only as delivery of scientific information but also transfers personalities to form students with character. A question must be given to the teacher about an example, whether a teacher is required to be a good role model only when in teaching and learning activities or all activities in his daily life? With that question, the profession, the role, and responsibilities as an exemplary teacher can be done in teaching and learning in the classroom and a good environment outside the classroom.

Gerstner in Jamal Ma'mur Asmani states that the teacher's role is not only as a teacher but also plays a role as:

1) Coach 
Professional teachers must be able to act as sports teachers. $\mathrm{He}$ mostly helps his students in the game. As a trainer, teachers must always motivate their students to master the subject matter, work hard and achieve high achievements.

2) Counselour

Professional teachers must be able to become friends and role models of students and be able to create a conducive learning atmosphere.

3) Manager learning Professional teachers must also act like company managers. He must be able to organize and condition the learning process of his students. On the other hand, he must also mingle as part of the students and participate in learning with them ${ }^{17}$.

17 Jamal Ma'mur Asmani, Tips Menjadi Guru Inspiratif, Kreatif, Dan Inovatif (Yogyakarta: Diva Press, 2014).
4) Teacher duties In-Law No. 14 of 2005, there are five main tasks of teachers, namely: 1) teaching, which is to convey knowledge

to students, 2) educators means that teachers continue and develop life values to students, 3) guiding is to show something good, 4) coach means the teacher develops skills and applies them in life for the future of the students, 5) evaluation, to determine the development of students 18 .

Several tasks must be carried out by the teacher, namely ${ }^{19}$ :

a. It is obligatory to know the characteristics that exist in children in various ways, namely: observation, interviews,

18 Syaiful Bahri Djamarah, Guru Dan Anak Didik (Jakarta: Rineka Cipta, 2010).

$19 \quad$ Ahmad Tafsir, Ilmu
Pendidikan Dan Perspektif Islam
(Bandung: Remaja Rosdakarya,
2016).


questionnaires and so on;

b. Try to help students develop good traits and emphasize bad traits so they don't develop;

c. Show students the tasks of adults by introducing various skills so that they imitate;

d. Conduct evaluations every time to find out the development of students going well;

e. Provide guidance and counselling when students have difficulty developing their potential.

When viewed from the details of the duties and responsibilities that must be carried out by teachers, especially Islamic education teachers, namely: ${ }^{20}$

a. Must put a sense of affection for students such as treatment of their children;

b. Do not expect merit or thanks, but intending to teach is to seek pleasure and draw closer to Allah;

c. Advise students every chance they get;

d. Prevent students from bad behavior;

e. Teachers must practice their knowledge and be honest in their actions.

Heri Jauhari Muchtar detailed the teacher's duties in teaching, namely: ${ }^{21}$

a. Carry out the teaching and learning process in unity;

b. Guard children in various aspects, namely knowledge, skills and development of all personalities;

c. Teach according to the level of development and maturity of the child;

d. Maintain the needs (needs) and talents of students;

e. Determine lesson objectives together with students so that they know the

21 Heri Jauhari Muchtar, Fikih (Bandung: Remaja Rosdakarya, 2007). 
achievement of these goals;

f. Give encouragement, appreciation, and rewards to students;

g. Make teaching materials and methods related to real life, so that they know what is being learned is useful;

h. Divide subject matter into units and focus on problems;

i. Avoid futile actions and providing meaningless

information, as well as avoiding penalties and repetition of work;

j. Engaging students in active learning according to their abilities and talents;

k. Color learning with warmth, brotherhood, and please help and be tolerant, because it will affect the response of students both intellectually, socially, and morally.

Thus, it can be understood that the task of educators as teachers, motivators and facilitators in the teaching and learning process that all the potential of students can be realized properly.

\section{Building Moral Learners}

1. Definition of moral

In Indonesian, the word moral means morals or morality, which implies discipline that guides inner behavior in life. The word moral is taken from the Latin word mores, which means culture/habit. The word mores has the same meaning (synonym) as the word mos, moris manner mores or manners, morals.

According to Imam AlGhazali, morals or morals, namely the stability of the soul can give birth to actions easily without the need for thought and reflection. If every behavior born of the soul is good according to the standards of reason and religion, it is called good morals or morals (and vice versa).

2. Moral Awareness

Moral awareness is one of the critical components of human behavior and actions; behaving morally will make the actions follow applicable norms. Such moral understanding will be based on values 
that are truly essential and fundamental.

Human

behavior is based on moral awareness, then his behavior and actions will always be carried out as they should, anytime and anywhere.

For people who have moral awareness even if they are not supervised, and no one is watching them, then every moral action will always be done anywhere and anytime. Because what becomes his behavior and action is based on awareness, not based on lust and any power nor is it imposed but is based on the "power" of moral consciousness itself.

According to Van Magnis, there are three important components of moral awareness, including:

a. Having a feeling of obligation or obligation to take moral action will happen in every human conscience and heart, to anyone, anywhere, anytime. If you pay attention, it will be seen that if these obligations cannot be changed and negotiated because it is a form of obligation, then if the word is not obeyed in implementation, it means a moral violation;

b. Rational moral consciousness can be said to be rational because it is generally accepted and open to justification or denial. In the matter of moral consciousness

rationality, humans believe that they will arrive at the same opinion as a moral issue, as long as they are free from coercion and pressure, do not seek their gain, impartial, willing to act under generally accepted rules;

c. Freedom, a moral awareness, is free to obey it, free in determining one's behavior and in that determination at the same time displaying the value of the human being himself 22 .
22 Ach. Charris Zubair, Kuliah Etika, ed. 3 (Jakarta: Bumi Aksara, 2011). 
3. Moral Stage

a. Moral knowing is an important thing to teach; there are six things, namely: moral awareness, (2) knowing moral values, (3) perspective taking or understanding thoughts people, (4) moral rationing or moral considerations, (5) decision making, and (6) self-knowledge or the ability to know oneself.

This stage is the first step that must be carried out in implementing character education;

b. The moral feeling is a source of energy in humans to behave by moral principles. There are six things: (1) conscience (conscience), confidence, empathy (feel what others feel), (4) loving the truth (loving the truth), (5) self-control (able to control oneself), and (6) humility (humility). The teacher's target is the student's emotional dimension, the student's heart, and soul. This stage is a consolidation of the emotional aspects of students to become individuals with character according to religious teachings;

c. Moral action (moral action) is a way to translate moral knowledge into real action. To find out someone in good deeds (act morality), there are three things, namely competence or having the authority, (2) will or will do something, and (3) habit or habit or prevalence ${ }^{23}$;

d. At this stage, it is the peak of success in character-building applications (namely, when students can consciously practice in everyday life);

4. Factors that influence Moral of Learners

Several factors affect the morale of students, namely:

23 Mansur Muslih, Pendidikan Karakter Menjawab Tantangan Krisis Multidemensional (Jakarta: Bumi Aksara, 2011). 
a. Lack of attention and religious education by the family.

It needs to be understood that the existence of parents in the family environment is one of the public figures or role models by children even in everyday life and activities, including in aspects of daily life, but in religious education, it seems as though it will be neglected. Thus a new generation will be born who act not under religious teachings and are materialistic;

b. The influence of the environment is not good.

The environment is one factor that can influence adolescents both who live in villages and those who live in big cities which lead individualistic and materialistic lives. So that when they pursue this mundane and luxury, they can do whatever they want without first paying attention to whether it is against religion or not, good or bad;

c. Psychological pressure experienced by adolescents

The pressure that occurs on adolescents will experience psychological pressure and disturbances when being in the house is caused by a divorce or a fight from the parents, which causes the child to feel uncomfortable at home and causes him to seek an outlet;

d. Failure in studies/education Adolescents who fail in education or do not get an education have a lot of free time; if that time is not used properly, it can be a bad thing when he is acquainted with things that are not good to fill the void of time;

e. The Role of Mass Media

The existence of mass media will make groups or groups easily influenced 
because teenagers are looking for their own identity so that they can easily imitate or imitate what they see, such as in violent movies or news, and so on;

f. The development of modern technology

The development of modern technology, such as accessing information quickly, easily, and without limits, also makes it easier for teenagers to find entertainment that is not suitable for them.

5. Building Moral-religious for future generations

Moral life cannot be separated from religious beliefs. Because the moral values are firm, they will remain unchanged because circumstances, place, and time are values that come from Religion. Therefore, in the development of the younger generation, it is necessary for moral and religious life to be in line and receive serious attention.

In building the next generation, the role of parents is very important because coaching means the coaching of all aspects of their lives, especially personal coaching that begins from the birth of the child, even from the womb. In addition, we need to realize that personal and moral coaching occurs through all aspects of life experience, both through sight, hearing and experience. So the younger the child, the more he associates with his mother, and the more he absorbs the experience that will help build his personality from his mother. Therefore, the role of women is very important in the development of the younger generation.

a. The problem of the moral life of the young generation today. The blurring of values in the younger generation's eyes is a major issue that is very prominent today. This is clear in those in their teens, especially those living in the big cities of Indonesia, who are trying to develop themselves towards a supposedly advanced 
and modern life, where a tumultuous variety of foreign cultures enter as if without a filter. They are confronted with various contradictions and various moral experiences, which cause them to be confused to choose which one is good for them;

b. How to deal with problems

1) Incoming foreign cultures need to be screened selectively to prevent negative cultures from being anticipated to spread;

2) Intensive Islamic religious education must be done to the maximum, both in the family environment, school

environment, and community, so that religious life is well guaranteed and then good moral values will become part of our nation;

3) It is necessary to do special education for adults in the field of mental health to avoid the shock of the soul to create peace and happiness in life at home and in society;

4) There needs to be a consulting agency to help people in need, both children, adolescents, and adults;

5) In the coaching activities, the government with its authority should take firm action and measures by involving all institutions, scholars, and community leaders ${ }^{24}$.

\section{Conclusion}

The role model exemplified by educators has implications for students' personalities. Educators are the first people in formal institutions who directly interact with students during teaching and learning processes. The roles and responsibilities of teachers in

24 Zakiah Daradjat, Ilmu Jiwa Agama, 2nd ed. (Jakarta: Bulan Bintang, 2011). 
building learners' morality through as seen from the database, are mostly centered as role models for students. Additionally, educators become models to be selected by students other than parents. Educators are also commonly known as trainers who encourage students to improve their knowledge. Finally, educators are managers who command students the correct way of learning, and counselors who advise students by choosing various alternative disciplines according to their talents and interests.

\section{References}

Al-Abrasyi, M. Athiyah. Dasar-Dasar Pokok Pendidikan Islam. 2nd ed. Jakarta: Bulan Bintang, 2000.

Al-Mighwar, Muhammd. Psikologi Remaja. 2nd ed. Bandung: Pustaka Setia, 2011.

Asmani, Jamal Ma'mur. Tips Menjadi Guru Inspiratif, Kreatif, Dan Inovatif. Yogyakarta: Diva Press, 2014.

Bali, Muhammad Mushfi El Iq, and Nurul Fadilah. "Internalisasi Karakter Religius Di Sekolah Menengah Pertama Nurul Jadid." Jurnal
MUDARRISUNA: Media Kajian Pendidikan Agama Islam 9, no. 1 (July 2019):

$1-25$.

https://doi.org/10.2237 3/jm.v9i1.4125.

Daradjat, Zakiah. Ilmu Jiwa Agama. 2nd ed. Jakarta:

Bulan Bintang, 2011.

Daradjat, Zakiyah. Membina

Nilai-Nilai Moral Di

Indonesia. 2nd ed.

Jakarta: Bulan Bintang, 2010.

Depdiknas. Peraturan

Pemerintah Republik

Indonesia Nomor 74

tahun 2008 tentang Guru (2008).

- - - . Undang-Undang

Nomor 20 Tahun 2003

Tentang Sistem

Pendidikan Nasional." Jakarta, 2003.

- - - . Undang-Undang

Republik Indonesia

Nomor 14 Tahun 2005

Tentang Guru dan

Dosen. Lembaran

Negara Republik

Indonesia Tahun 2005

Nomor 157, Pub. L. No.

110, 11 (2005).

Djamarah, Syaiful Bahri. Guru

Dan Anak Didik. Jakarta:

Rineka Cipta, 2010.

Muchtar, Heri Jauhari. Fikih.

Bandung: Remaja

Rosdakarya, 2007.

Mulyasa, Enco. Menjadi Guru

Profesional. Bandung:

Remaja Rosdakarya, 2010.

Muslih, Mansur. Pendidikan 
Karakter Menjawab

Tantangan Krisis

Multidemensional.

Jakarta: Bumi Aksara, 2011.

Pulungan, Sahmiar.

"Membangun Moralitas

Melalui Pendidikan

Agama." Al-Hikmah:

Jurnal Agama Dan Ilmu

Pengetahuan 8, no. 1

(April 2011): 9-24.

Sachs, Judyth. "Teacher

Professionalism: Why

Are We Still Talking about It?" Teachers and

Teaching: Theory and Practice 22, no. 4 (May 2016): 413-25.

https:// doi.org/10.1080 /13540602.2015.1082732.

Shaleh, Abdul Rachman.

Pendidikan Agama Dan

Pembangunan Watak

Bangsa. Jakarta:

RajaGrafindo Persada, 2006.

Sutirna. Bimbingan Dan

Konseling: Pendidikan

Formal, Nonformal, Dan

Informal. Yogyakarta:

Andi Offset, 2013.

Sutisna, Deni, Dyah

Indraswati, and

Muhammad Sobri.

"Keteladanan Guru

Sebagai Sarana

Penerapan Pendidikan

Karakter Siswa." JPDI

(Jurnal Pendidikan Dasar

Indonesia) 4, no. 2

(October 2019): 29.

https:// doi.org/10.2673

7/jpdi.v4i2.1236.
Syah, Muhibbin. Psikologi Belajar. 2nd ed. Jakarta: RajaGrafindo Persada, 2013.

Tafsir, Ahmad. Ilmu

Pendidikan Dan Perspektif

Islam. Bandung: Remaja

Rosdakarya, 2016.

- - - . Ilmu Pendidikan Islami. Bandung: Remaja Rosdakarya, 2013.

Usman, Moh.Uzer. Menjadi Guru Profesional. 3rd ed. Bandung: Remaja Rosdakarya, 2010.

Zubair, Ach. Charris. Kuliah Etika. Edited by 3. Jakarta: Bumi Aksara, 2011. 
Kandiri et al.

128 | Nadwa: Jurnal Pendidikan Islam 